\title{
IDIOPATHIC OSTEO-ARTHRITIS OF THE HIP
}

\author{
BY \\ J. R. PEARSON AND D. M. RIDDELL \\ The Robert Jones and Agnes Hunt Orthopaedic Hospital, Oswestry, Shropshire
}

Recent work has been concentrated upon the pathological anatomy of the osteo-arthritic hip (Harrison, Schajowicz, and Trueta, 1955; Roberts, 1953, 1955; Landells, 1953; Rhaney and Lamb, 1955). We have studied the disease from the clinical aspect. All patients with osteo-arthritis of the hip seen in the Robert Jones and Agnes Hunt Orthopaedic Hospital, Oswestry, in the last 15 years have been reviewed. We have excluded all those in whom insufficient information was available, and all those in whom the osteo-arthritis was considered to be secondary to a previous disorder of the hip joint, such as congenital dislocation of the hip, slipped upper femoral epiphysis, and rheumatoid arthritis.

Patients in all stages of the disease were seen, and we were able to follow the progress of the disorder for periods of from 4 to 15 years. From the data so collected we have been able to divide osteoarthritic hips into two clinical and radiological groups.

\section{Material Studied}

Out of 780 patients, 400 (203 men and 197 women) who have not had a major operation have been studied with particular reference to their clinical state and to the progress of the disease. These features have been correlated with the radiographic findings.

Age.-The age groups of the patients when first seen are shown in Fig. 1; the range was 35 to 85 years, more than three-quarters of the patients being over 50 years old.

Presenting Symptoms.-These are listed in Table I; 363 patients presented with pain in or referred from the osteo-arthritic hip, in two-thirds to the region of the greater trochanter, in the rest to the knee, the groin, and the back of the thigh. 21 patients presented complaining of low back pain only, the osteo-arthritic hip being found incidentally; in these patients the pain may have been due to degenerative changes in the lumbar spine, but the osteo-arthritic hip itself probably contributed to it.

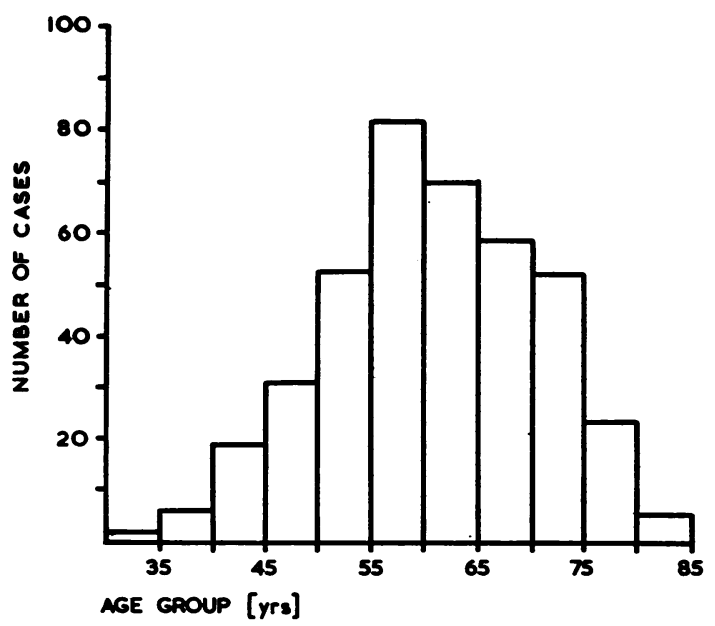

Fig. 1.-Age at time of presentation of $\mathbf{4 0 0}$ patients with idiopathic osteo-arthritis of the hip.

Sixteen patients presented with symptoms related to conditions other than the osteo-arthritic hips, the osteoarthritis being brought to light by questioning and examination.

TABLE I

PRESENTING SYMPTOMS OF 400 PATIENTS WITH PRIMARY OSTEO-ARTHRITIS OF THE HIP

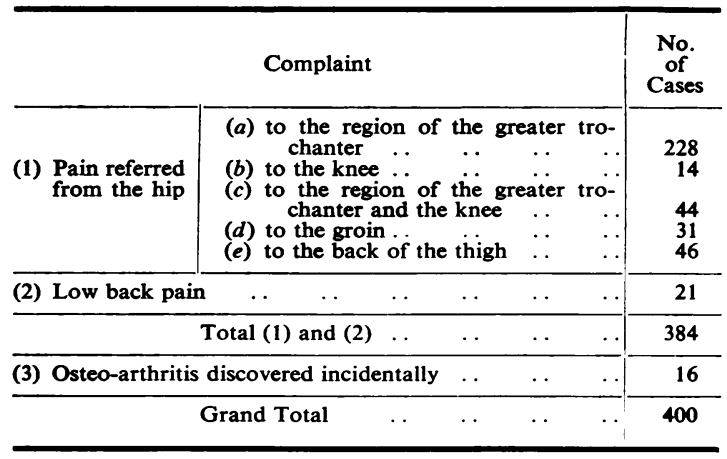


The severity of pain was estimated by the dosage of analgesics necessary to control it, the presence of night pain, the distance the patient could walk, and the need to use one or two sticks. It was found that there was no relation between the degree of limitation of movement and the radiological appearances and intensity of pain.

No patient complained primarily of stiffness. The length of history varied from one week to many years, and had no correlation with the stage of the osteoarthritis. In 49 patients the symptoms began after an injury to the hip.

Radiographs. - In each case a series of radiographs was available, the series extending over several years. These were examined with regard to the following points:

(1) The degree and site of diminution in "joint space":

(2) The amount and site of sclerosis:

(3) The presence and sites of cyst formation:

(4) The sites of osteophytes.

\section{Results}

Clinical and radiological examination showed that the disease falls into two patterns, each of which possesses distinct characteristics, all the cases reviewed conformed to one of these patterns.

The early stages of both patterns are similar. The initial loss of movement is always one of internal rotation and of extension. In all cases, further limitation of extension leads to a flexion deformity, and, at the same time, limitation of flexion occurs. The subsequent progress of the disease differs in the two types.

Adduction-External Rotation Type.-Abduction and external rotation decreases, and finally all sideto-side movement is lost. The final position is one of flexion, adduction, and external rotation, either quite stiff, or with a few degrees of free flexion and no other movement.

Radiologically, the maximal loss of "joint space" and the greatest degree of sclerosis and cyst formation appear in the superior part of the joint (Fig. 2). Osteophytes are present all round the acetabular margin and around the rim of the head of the femur (Fig. 3, opposite). In these hips, upward subluxation of the head of the femur often occurs (Fig. 4, opposite). The neck may present a valgus appearance (Fig. 5, opposite). A buttress is seen on the inferior border of the neck, and is often present before the development of an adduction deformity (Fig. 6, opposite).

Fig. 7 (overleaf) shows that this buttress is situated in the postero-inferior part of the neck: the significance of this buttress has been discussed by Wiberg (1939) and Roberts (1953).

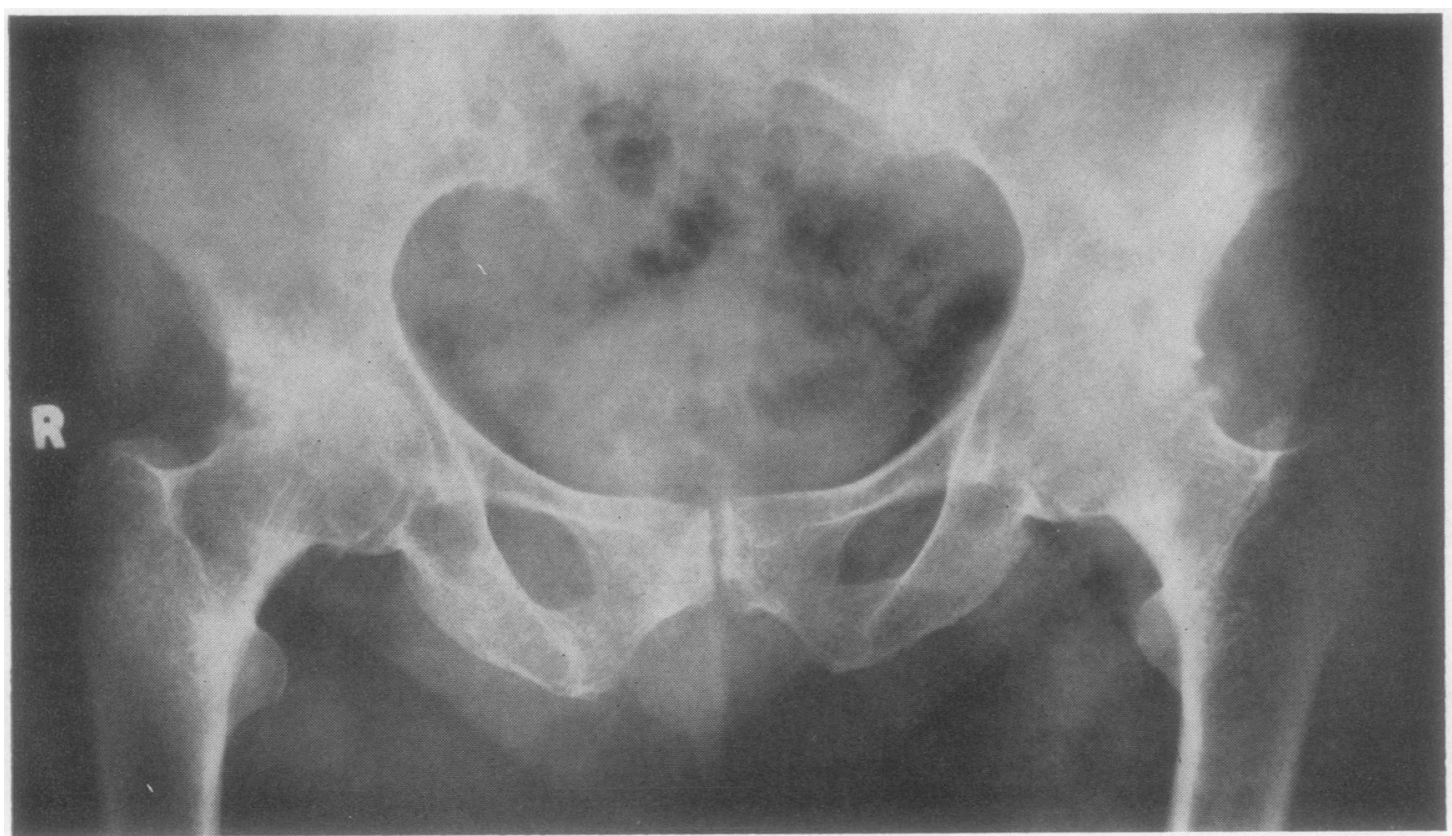

Fig. 2.-Early case of adduction-external rotation, showing maximal loss of "joint space", and greatest sclerosis and most cysts in the superior part of the joint, left hip.

Right Hip: $30^{\circ}$ fixed flexion deformity, $5^{\circ}$ fixed adduction and external rotation deformity. Free flexion 65 , virtually no other movement. Left Hip: $10^{-}$fixed deformity. Free flexion $90^{\circ}$, a few degrees of abduction and adduction, no rotation. 


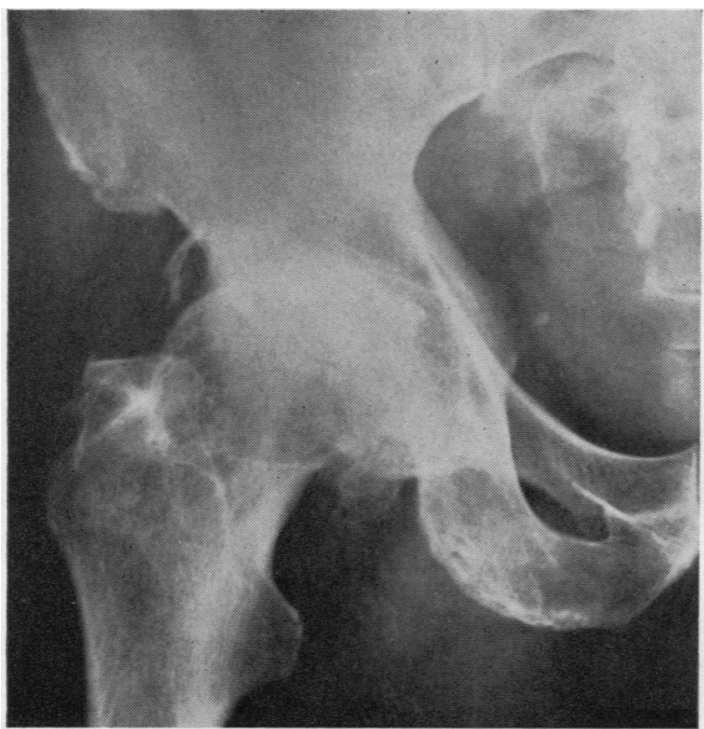

Fig. 3.-Adduction-external rotation, showing osteophytes on femoral head and at acetabular margins.

Right Hip: 40* external rotation deformity with marked limitation of movement.

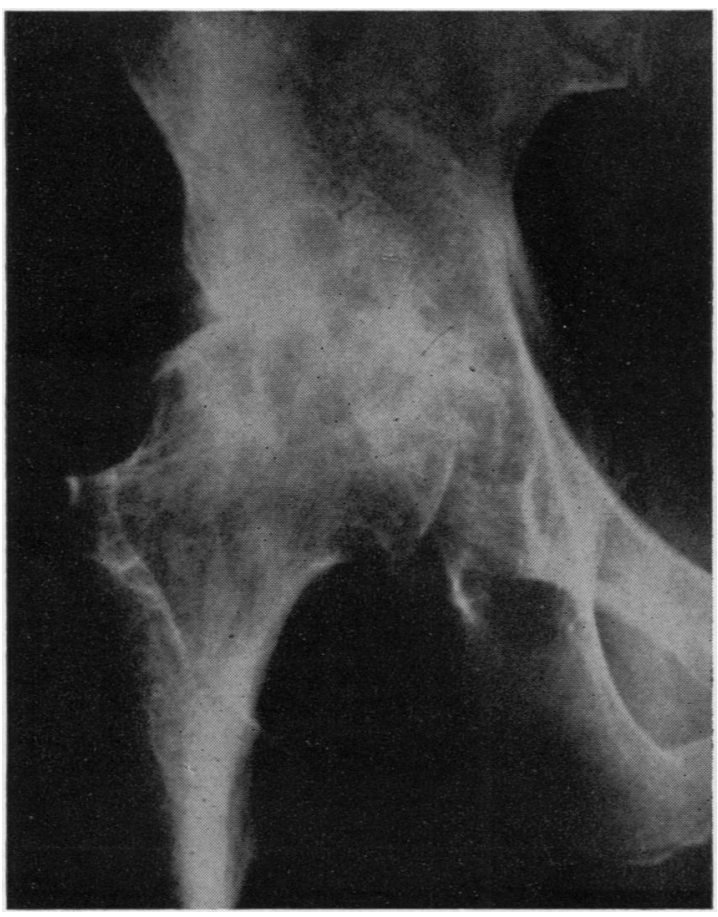

Fig. 5.-Advanced adduction-external rotation, showing valgus appearance of the neck.

Right Hip: $30^{\circ}$ flexion deformity, $5^{\circ}$ external rotation deformity. Free flexion to $70^{\circ}$, a few degrees of abduction and adduction.

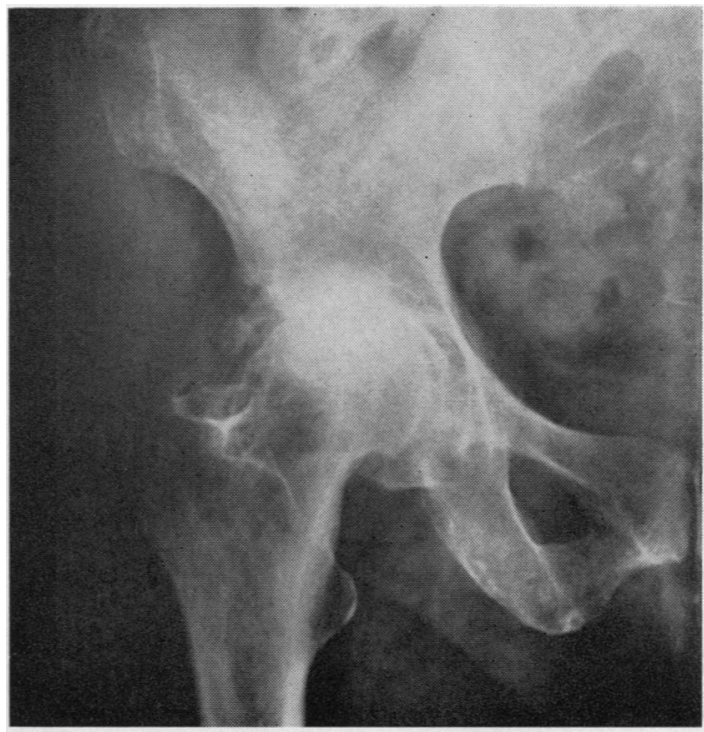

Fig. 4.-Adduction-external rotation with upward subluxation developing.

Right Hip: $40^{\circ}$ fixed flexion deformity, $15^{\circ}$ fixed adduction and $40^{\circ}$ fixed external rotation deformity. A jog of movement only.

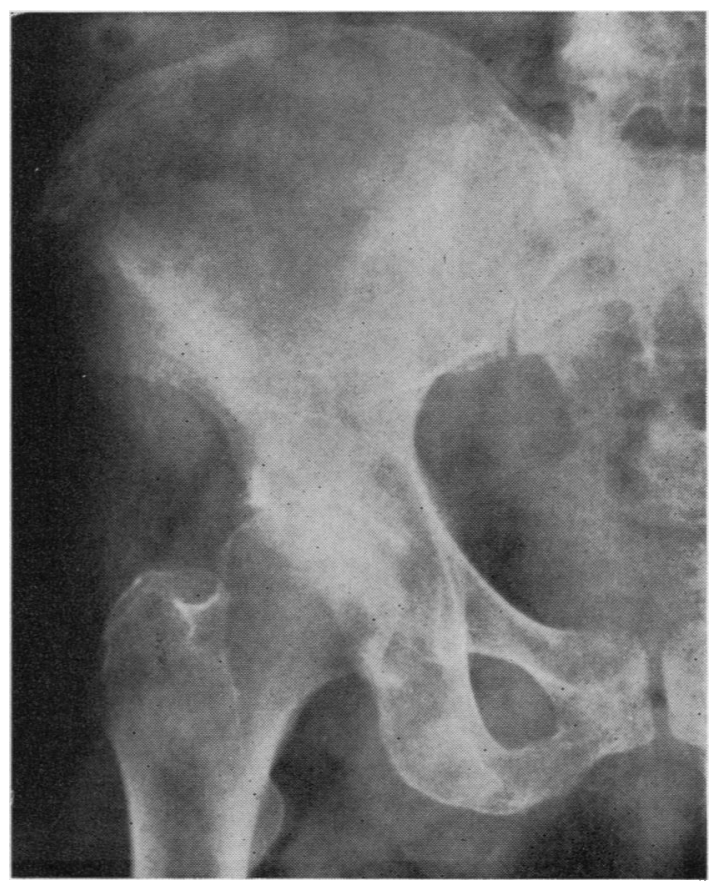

Fig. 6.-Adduction-external rotation, showing inferior buttress. Right Hip: A few degrees fixed flexion deformity. Free flexion to $90^{\circ}$, abduction $15^{\circ}$, adduction $15^{\circ}$, external rotation $10^{\circ}$, internal rotation nil. 


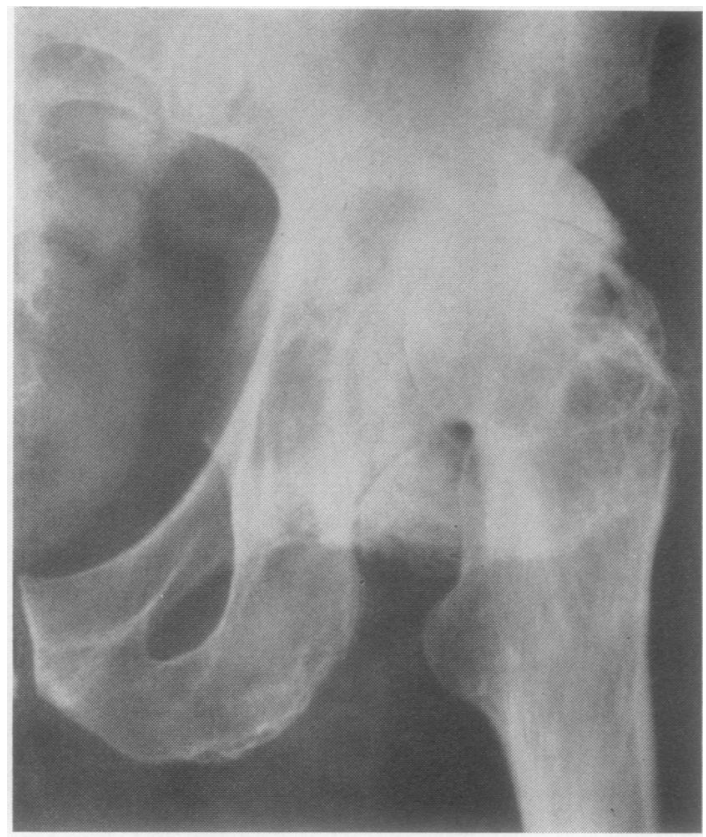

Fig. 7.-Adduction-external rotation.

Left Hip: Laternal view of neck, showing posterior and inferior position of buttress.

Non-Adducted Type.-Adduction and external rotation decrease, until all side-to-side movement is lost, so that the final position is one of flexion and external rotation, either in neutral abduction adduction or with an abduction deformity-an adduction deformity is unknown in this type. As in the first type, the hip may be completely stiff or may retain a few degrees of free flexion.

Radiologically, the greatest loss of "joint space", and the greatest sclerosis and cyst formation appear medially in the deepest part of the joint (Fig. 8). Osteophytes are present around the acetabular margin and around the rim of the head of the femur (Fig. 9).

These hips progress to a central subluxation (Fig. 10, opposite). The appearance of a buttress is seen to occur superiorly in the neck (Fig. 11, opposite).

The majority have the appearance of a varus neck (Fig. 12, overleaf), although this is not invariable, some of these cases being associated with a valgus neck.

The adduction-external rotation type was found in 311 patients and the non-adducted type in 89

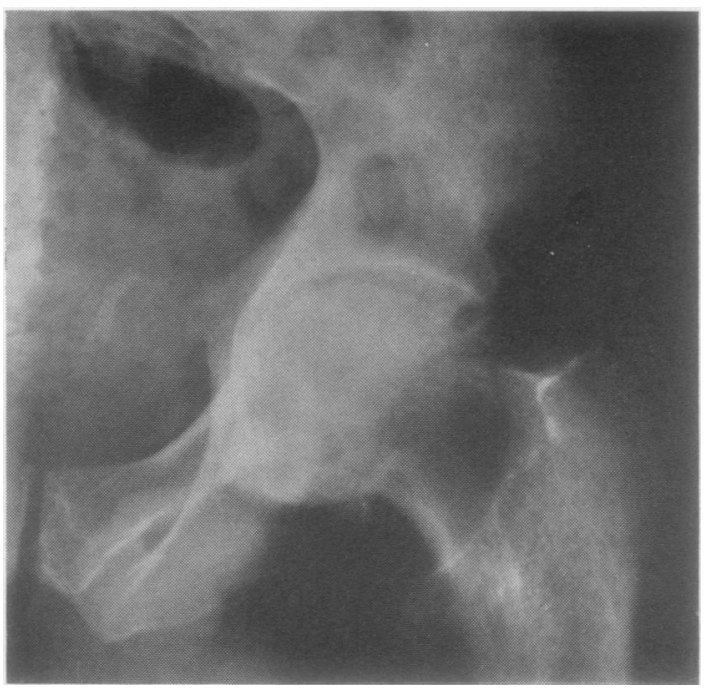

Fig. 8.- Non-adducted, showing greatest loss of "joint space" and greatest sclerosis and cyst formation medially.

Left Hip: $70^{\circ}$ fixed flexion deformity. Free flexion $45^{\circ}$. abduction $5^{3}$, adduction nil, rotations nil.

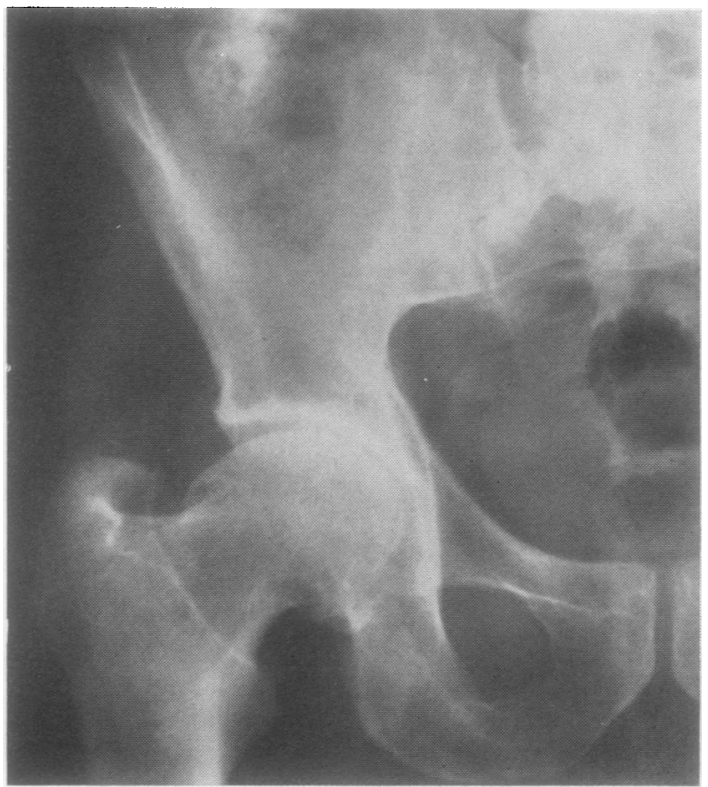

Fig. 9.-Non-adducted, showing femoral head osteophytes and acetabular marginal osteophytes.

Right Hip: $5^{\circ}$ fixed flexion deformity. Free flexion $90^{\circ}$, abduction and adduction limited by one-third, internal rotation nil. 


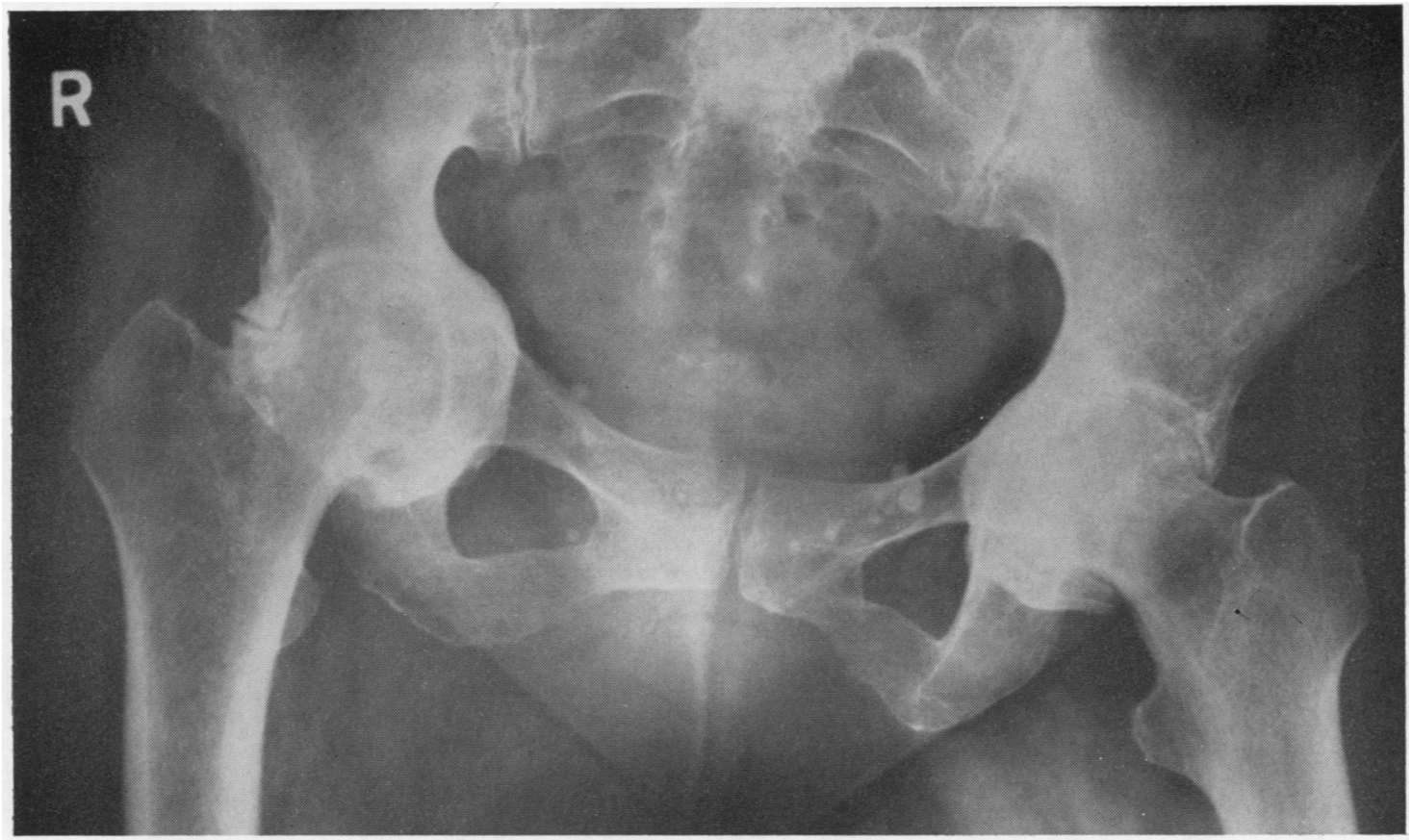

Fig. 10.-Non-adducted, showing central subluxation.

Right Hip: Fixed flexion deformity $40^{\circ}$. No movement.

Left Hip: Fixed flexion deformity $60^{\circ}$, external rotation deformity $10^{\circ}$. Free flexion $90^{\circ}$, no other movement.

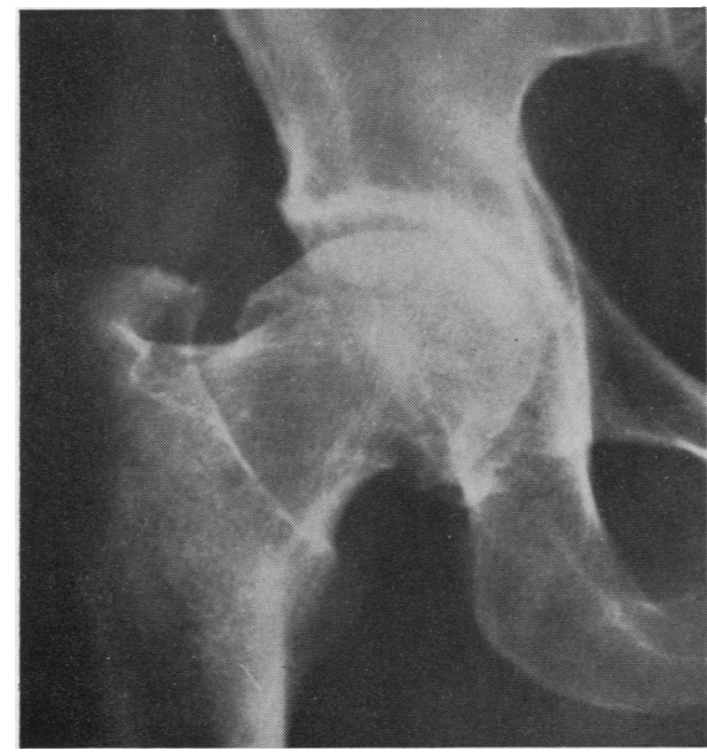

Fig. 11.-Non-adducted, showing superior buttress.

Right Hip: No fixed deformity. Flexion full, abduction $20^{\circ}$, adduction $15^{\circ}$, internal rotation nil. patients. The large proportion of the second type is notable in view of the widely-held belief that all osteo-arthritic hips adduct. It is even possible for both types to occur in the same patient (Fig. 13, overleaf).

Progression of the Disease.-When studied over a period of time, most of the patients were found to continue to suffer pain of variable severity, but restriction of their activities relieved pain adequately in many cases. In seven patients the hip became painless, five of them had arthritis of the adductionexternal rotation type and two of the non-adducted type. We were, however, unable to predict which patients would develop this happier outcome.

Using the rate of decrease of hip movement and the development of a contracture as criteria, the rate of progress of the disease was seen to be more rapid in active persons. The average time from the onset of pain to almost complete loss of movement in the hip was 8 years (range 18 months to 23 years). Pain may start as soon as limitation of internal rotation and extension begins, but may not occur until the osteo-arthritis is far advanced. There was no difference in the rate of progress between the adduction-external rotation type and the nonadducted type. 


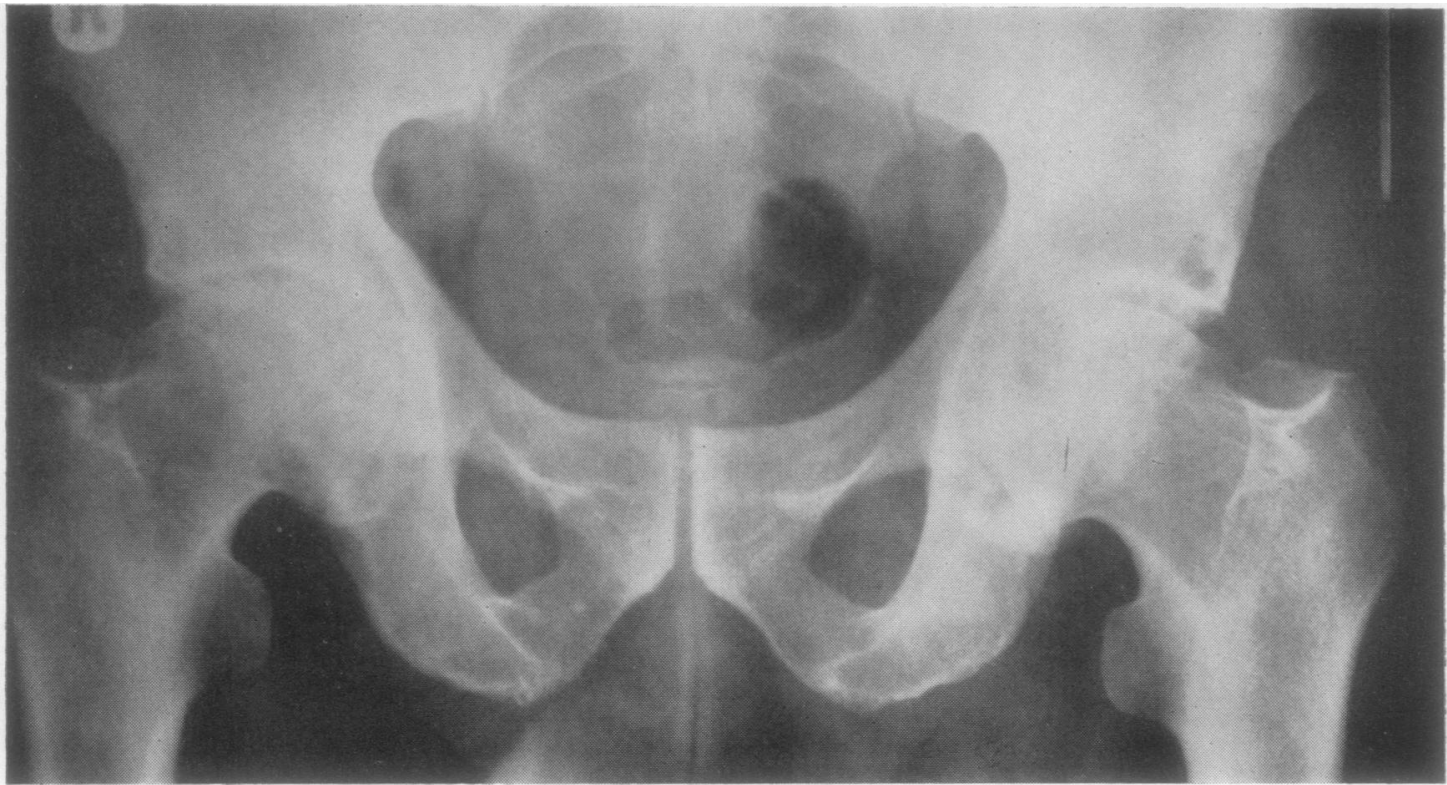

Fig. 12.-Non-adducted, showing appearance of a varus neck.

Right Hip: $20^{\circ}$ flexion deformity. Free flexion full, abduction $10^{\circ}$, adduction $10^{\circ}$, external rotation $10^{\circ}$, internal rotation $5^{\circ}$.

Left Hip: $15^{\circ}$ fixed flexion deformity. Free flexion full, abduction $10^{\circ}$. adduction $30^{\circ}$. external rotation $15^{\circ}$, internal rotation. nil.

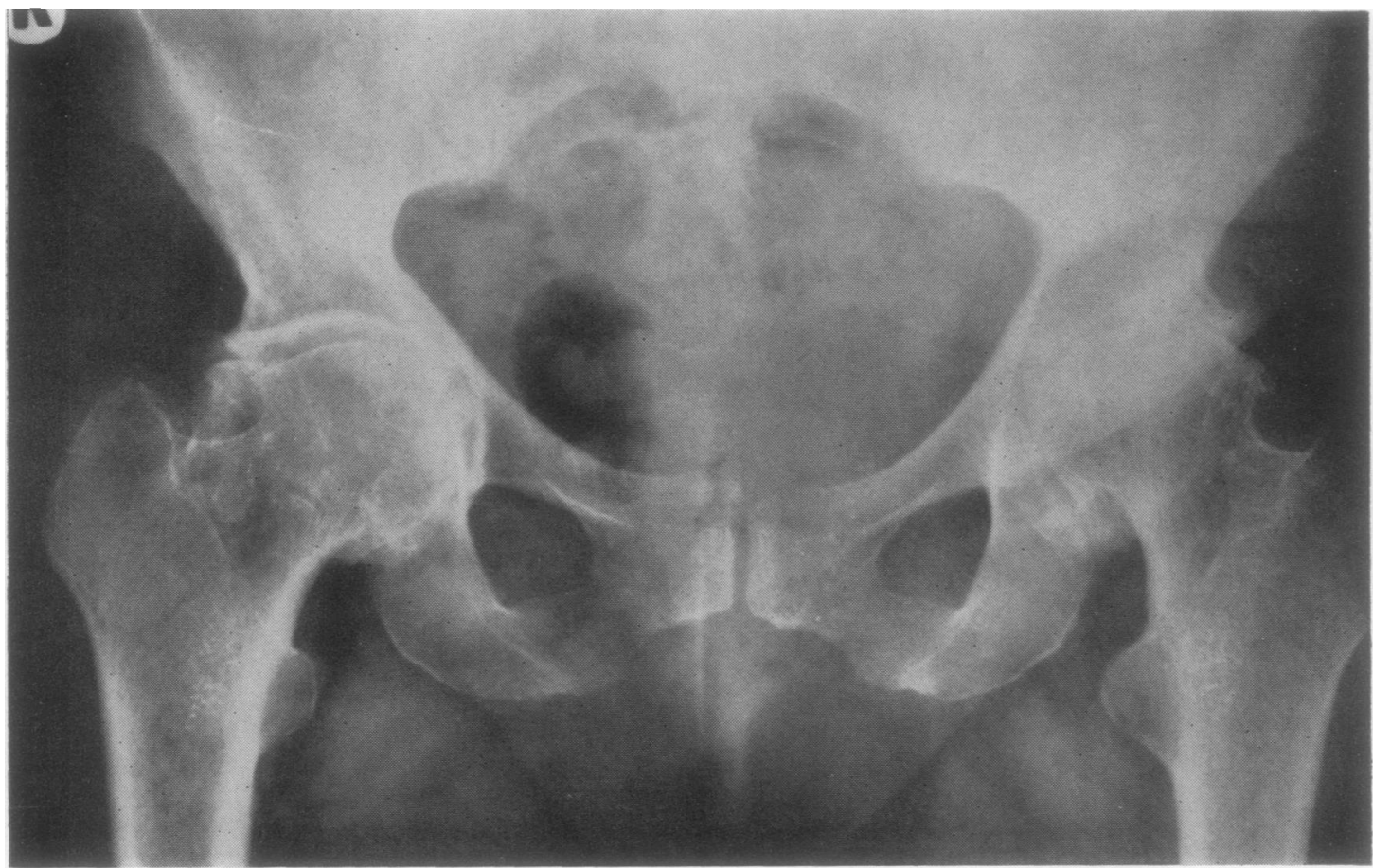

Fig. 13.-Adduction-external rotation on the left side and non- adduction on the right side. Right Hip: $30^{\circ}$ fixed flexion deformity. Free flexion to $60^{\circ}$, jog of abduction, no rotation. Left Hip: $70^{\circ}$ fixed flexion deformity, $5^{\circ}$ adduction deformity. No free movement. 
Radiological progression of the osteo-arthritis occurred in the following order:

(1) Loss of "joint space";

(2) Sclerosis and osteophytic changes appearing together;

(3) Cyst formation;

(4) Subluxation associated with flattening of the head.

Limitation of internal rotation and extension, and also a flexion contracture, are frequently found before obvious radiological evidence of the disease is present. On the other hand, marked radiological changes can be present with a surprisingly good range of movement.

\section{Discussion}

Limitation of movement of the hip joint can be due to any of the following factors: capsular contracture and muscle spasm, contracture of muscles and their overlying fascia (particularly the fascia over the ilio psoas), mechanical block due to osteophytes, and incongruity of joint surfaces. Capsular contracture and muscle spasm are probably the most important causes of true limitation of movement and of deformity of the hip. Bony block due to osteophytes is rare, and can occur only in the later stages of the disease when osteophyte formation is excessive. Similarly, limitation of movement due to incongruity of the joint surfaces can occur only when there is gross disorganization of the joint. Contracture of muscle and fascia are found in the presence of any long-standing deformity in the hip.

Walmsley (1928) reported that in the position of full extension of the hip the capsule is tight in all its components; it follows from this that contracture occurring in any part of the capsule must produce loss of extension, and must ultimately lead to a flexion contracture of the hip. Roberts (1953) has shown that, if the postero-inferior part of the capsule is contracted, a limitation of abduction and internal rotation will occur, leading to an adduction-external rotation deformity - this would correspond to the adduction-external rotation type.

We have correlated the clinical feature of both types with the appearances at operation and of post mortem specimens. In the adduction-external rotation type, the capsule is thickened posteroinferiorly and division allows abduction and some internal rotation to occur. In the non-adducted type, the capsule is thickened postero-superiorly, and division above and behind relieves the abduction contracture, if present, and allows adduction and internal rotation to occur.

We examined microscopically pieces of capsule excised from the postero-superior and posteroinferior portion of the capsule in both types, and compared them with the thickness of the rest of the capsule. Fig. 14 shows the increase in the thickness of the capsule.

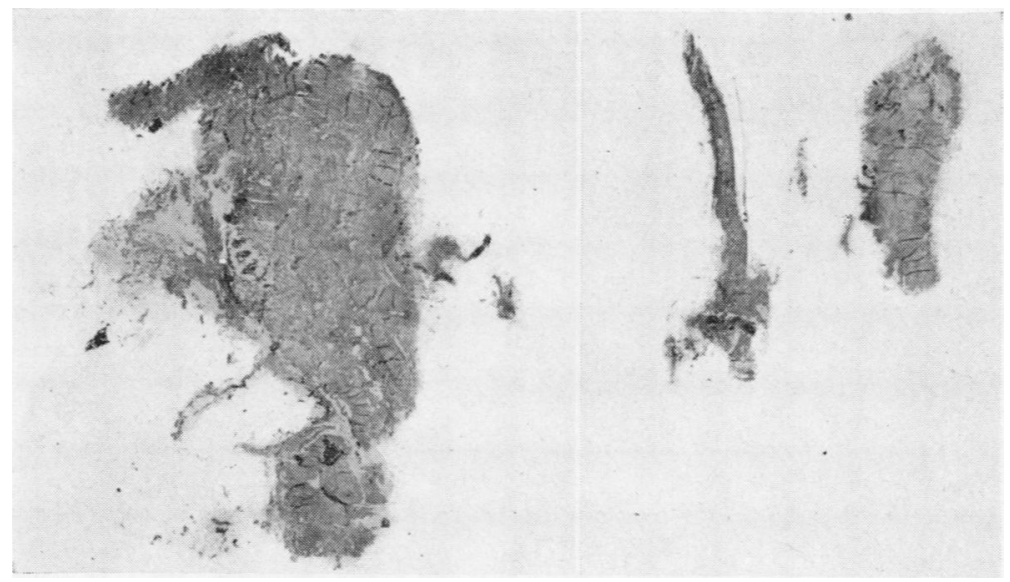

Fig. 14.-Microphotograph of capsule taken from an osteo-arthritic hip of the non-adducted type, showing increased thickness in the postero-superior portion. Left: Thickened capsule. Right: Normal capsule. 
The distance between the capsular attachments of the hip joint was measured on a dry specimen in varying positions of the joint, using an imaginary clock face on the acetabular rim and the base of the neck of the femur (Fig. 15).

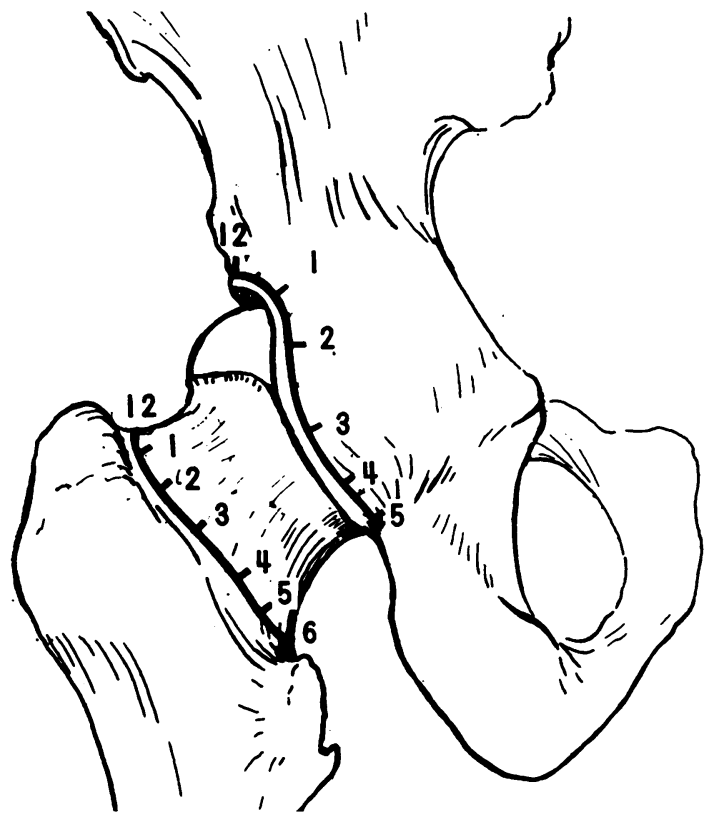

Fig. 15.-Posterior aspect of hip joint, showing line of attachment of capsule and points from which measurements were taken.
Table II shows that in adduction and external rotation deformity most shrinkage occurs posteroinferiorly, and that in abduction and external rotation deformity the greatest shrinkage occurs postero-superiorly.

In all these cases, the radiological findings can be correlated with this differential shortening in the capsule. Where this occurs postero-inferiorly, producing an adduction and external rotation deformity, the maximal strain falls on the superior part of the joint, leading to degenerative changes in this part of the joint and giving the radiological picture shown in the adduction-external rotation type.

When the capsular contracture is posterosuperior, leading to loss of adduction and ultimately to abduction deformity, the maximal strain falls on the medial part of the joint, producing degenerative changes here, and central subluxation, as seen in the non-adducted type. We do not feel that this capsule contracture is the initial cause of the deformity; it is probable that muscle spasm produces the initial deformity and that adaptive changes in the capsule occur later.

In this series of patients, various forms of conservative treatment were tried, including most forms of physiotherapy. Active stretching exercises, intended to prevent contracture occurring or progressing, relieved pain for a considerable period if the patients themselves continued to do these exercises diligently.

TABLE II

MEASUREMENT OF VARYING HIP POSITIONS ON DRY SPECIMENS OF ILIUM AND FEMUR OF CAPSULAR ATTACHMENT

(Average of ten measurements in millimetres + or - neutral position)

\begin{tabular}{|c|c|c|c|c|c|c|c|c|c|c|c|c|c|}
\hline \multirow{2}{*}{\multicolumn{2}{|c|}{$\begin{array}{l}\text { Position of Hip } \\
\text { No flexion }\end{array}$}} & \multicolumn{12}{|c|}{ Clock Measurements } \\
\hline & & 12 to 12 & 1 to 1 & 2 to 2 & 3 to 3 & 4 to 4 & 5 to 5 & 6 to 6 & 7 to 7 & 8 to 8 & 9 to 9 & 10 to 10 & 11 to 11 \\
\hline $\begin{array}{l}\text { Neutral Abduction- } \\
\text { Adduction } \\
\text { Neutral Internal or } \\
\text { External Rotation }\end{array}$ & $\cdots$ & - & - & - & - & - & - & - & - & - & - & - & - \\
\hline $\begin{array}{l}20^{\circ} \text { Internal Rotation } \\
\text { Neutral Abduction- } \\
\text { Adduction }\end{array}$ & $\cdots$ & $\begin{array}{r}30 \\
-1\end{array}$ & $\begin{array}{r}45 \\
+3\end{array}$ & $\begin{array}{r}49 \\
+1\end{array}$ & $\begin{array}{r}51 \\
+6\end{array}$ & $\begin{array}{r}48 \\
+9\end{array}$ & $\begin{array}{r}40 \\
+5\end{array}$ & $\begin{array}{r}40 \\
-1\end{array}$ & $\begin{array}{r}28 \\
+1\end{array}$ & $\begin{array}{r}12 \\
-13\end{array}$ & $\begin{array}{r}13 \\
-12\end{array}$ & $\begin{array}{r}12 \\
-8\end{array}$ & $\begin{array}{r}21 \\
+1\end{array}$ \\
\hline $\begin{array}{l}20^{\circ} \text { Abduction } \\
\text { Neutral Rotation }\end{array}$ & $\cdots$ & $\begin{array}{r}24 \\
-7\end{array}$ & $\begin{array}{r}37 \\
-5\end{array}$ & $\begin{array}{r}42 \\
-6\end{array}$ & $\begin{array}{r}48 \\
+3\end{array}$ & $\begin{array}{r}44 \\
+5\end{array}$ & $\begin{array}{r}40 \\
+5\end{array}$ & $\begin{array}{r}41 \\
0\end{array}$ & $\begin{array}{r}32 \\
+5\end{array}$ & $\begin{array}{r}27 \\
+2\end{array}$ & $\begin{array}{r}20 \\
-5\end{array}$ & $\begin{array}{r}17 \\
-3\end{array}$ & $\begin{array}{r}16 \\
-4\end{array}$ \\
\hline $\begin{array}{l}20^{\circ} \text { External Rotation } \\
\text { Neutral Abduction- } \\
\text { Adduction }\end{array}$ & $\cdots$ & $\begin{array}{r}29 \\
-2\end{array}$ & $\begin{array}{r}38 \\
-4\end{array}$ & $\begin{array}{r}38 \\
-10\end{array}$ & $\begin{array}{r}36 \\
-9\end{array}$ & $\begin{array}{r}32 \\
-7\end{array}$ & $\begin{array}{r}27 \\
-8\end{array}$ & $\begin{array}{r}40 \\
-1\end{array}$ & $\begin{array}{r}33 \\
+6\end{array}$ & $\begin{array}{r}33 \\
+8\end{array}$ & $\begin{array}{r}33 \\
+8\end{array}$ & $\begin{array}{r}30 \\
+10\end{array}$ & $\begin{array}{r}27 \\
+7\end{array}$ \\
\hline $\begin{array}{l}20^{\circ} \text { Adduction } \\
\text { Neutral Rotation }\end{array}$ & $\cdots$ & $\begin{array}{r}34 \\
+3\end{array}$ & $\begin{array}{r}42 \\
0\end{array}$ & $\begin{array}{r}44 \\
-4\end{array}$ & $\begin{array}{r}44 \\
-1\end{array}$ & $\begin{array}{r}38 \\
-1\end{array}$ & $\begin{array}{r}28 \\
-7\end{array}$ & $\begin{array}{r}35 \\
-6\end{array}$ & $\begin{array}{r}26 \\
-I\end{array}$ & $\begin{array}{r}25 \\
O\end{array}$ & $\begin{array}{r}28 \\
+3\end{array}$ & $\begin{array}{r}29 \\
+9\end{array}$ & $\begin{array}{r}28 \\
+8\end{array}$ \\
\hline $\begin{array}{l}20^{\circ} \text { Abduction } \\
20^{\circ} \text { External Rotation }\end{array}$ & $\begin{array}{l}\cdots \\
\cdots\end{array}$ & $\begin{array}{r}34 \\
+3\end{array}$ & $\begin{array}{r}35 \\
-7\end{array}$ & $\begin{array}{r}37 \\
-11\end{array}$ & $\begin{array}{r}38 \\
-7\end{array}$ & $\begin{array}{r}35 \\
-4\end{array}$ & $\begin{array}{r}30 \\
-5\end{array}$ & $\begin{array}{r}40 \\
-1\end{array}$ & $\begin{array}{r}35 \\
+8\end{array}$ & $\begin{array}{r}34 \\
+9\end{array}$ & $\begin{array}{r}34 \\
+9\end{array}$ & $\begin{array}{r}31 \\
+11\end{array}$ & $\begin{array}{r}26 \\
+6\end{array}$ \\
\hline $\begin{array}{l}20^{\circ} \text { Adduction } \\
20^{\circ} \text { External Rotation }\end{array}$ & $\cdots$ & $\begin{array}{r}39 \\
+8\end{array}$ & 42 & $\begin{array}{r}38 \\
-10\end{array}$ & $\begin{array}{r}33 \\
-12\end{array}$ & $\begin{array}{r}19 \\
-20\end{array}$ & $\begin{array}{r}18 \\
-17\end{array}$ & $\begin{array}{r}31 \\
-10\end{array}$ & $\begin{array}{r}30 \\
+3\end{array}$ & $\begin{array}{r}35 \\
+10\end{array}$ & $\begin{array}{r}39 \\
+14\end{array}$ & $\begin{array}{r}39 \\
+19\end{array}$ & $\begin{array}{r}39 \\
+19\end{array}$ \\
\hline
\end{tabular}


When real or apparent shortening had occurred in the later stage of osteo-arthritis, a "raise" to the shoe on the affected side was the most effective way of relieving pain, particularly if it was combined with the use of a stick and restriction of activities.

\section{Summary}

(1) 400 patients with idiopathic osteo-arthritis of the hip treated conservatively have been reviewed.

(2) Two clinical and radiological patterns have been described, and their causation discussed and related to the area of capsular contracture.

(3) The final position of the hip may be one of flexion, adduction, and external rotation deformity, or one of flexion, external rotation, and neutral or slight abduction deformity. This depends mainly upon the site of capsular contracture.

We wish to thank D. Lloyd Griffiths, Director of the Department of Orthopaedics, Manchester Royal Infirmary, and Robert Roaf, Director of Clinical Studies and Research, the Robert Jones and Agnes Hunt Orthopaedic Hospital, Oswestry, for their great help and encouragement in writing this paper, the Consultant Staff of the Robert Jones and Agnes Hunt Orthopaedic Hospital, Oswestry, for allowing us to review their patients. Our thanks are also due to Dr. R. Ollerenshaw, Department of Medical Illustration, Manchester Royal Infirmary, to Beverley Southern, clinical photographer, and to our secretary, Mrs. Meriel Jackson.

\section{REFERENCES}

Harrison, M. H. M., Schajowicz, F., and Trueta, J. (1953). J. Bone Jt Surg., 35B, 598.

Landells, J. W. (1953). Ibid., 35B, 643.

Roberts, G. C. Lloyd (1953). Ibid., 35B, 627. (1955). Ibid., 37B, 8.

Rhaney, K., and Lamb, D. W. (1955). Ibid., 37B, 663. Walmsley, T. (1928). Ibid., 10, 40.

Wiberg, G. (1939). Acta chir. scand., 83, Suppl. 58.

\section{Coxarthrose idiopathique}

RÉSUMÉ

(1) On passe en revue 400 cas de coxarthrose idiopathique, traités par des procédés non sanglants.

(2) On décrit deux types cliniques et radiologiques, on discute leurs causes et on indique le rapport entre celles-ci et des régions de contracture capsulaire.

(3) En position finale la hanche peut présenter une déformation en flexion, adduction et rotation externe ou bien en flexion, rotation externe et abduction légère ou neutre. Cela dépend surtout du siège de la contracture capsulaire.

\section{Osteoartritis idiopática de la cadera Sumario}

(1) Se revistan 400 casos de osteoartritis idiopática de la cadera tratados sin intervención quirúrgica.

(2) Se describen dos tipos clínicos y radiológicos y se discuten sus causas, relacionándolas con regiones de contractura capsular.

(3) En posición final la cadera puede presentar una deformación en flexión, aducción y rotación externa o en flexión, rotación externa y abducción ligera o neutra. Esto estriba sobre todo en el sitio de la contractura capsular. 